\title{
Risks of Offshore Oil Drilling: Causes and Consequences of British Petroleum Oil Rig Explosion
}

\author{
Abednego Aryee (Corresponding author) \\ Department of Geography, Ryerson University \\ 350 Victoria Street, Toronto, Ontario, M5B 2K3, Canada \\ Tel: 1-416-979-5000 ext. 6905 E-mail: aaryee@ryerson.ca
}

Received: October 27, 2012 Accepted: December 5, 2012 Published: January 1, 2013

doi:10.5296/ast.v1i1.2843 URL: http://dx.doi.org/10.5296/ast.v1i1.2843

\begin{abstract}
The British Petroleum oil rig explosion in the Gulf of Mexico has left a legacy of environmental pollution, loss of businesses and health effects. The various stakeholders; British Petroleum, Harliburton, government regulators and Transocean Management Ltd are partly responsible for the safety of Macondo oil rig and they are accountable for negligence, oversight, cost-cutting and shoddy technical fixes which eventually resulted in the explosion. Several species of wildlife and ecosystems were threatened. Efforts were made to cap the well, clean the oil, and rehabilitate affected animals. In spite of the ongoing restoration efforts, there is still uncertainty regarding long-term viability of restored ecosystems.
\end{abstract}

Keywords: Oil spill, Impact, Clean up, Regulation 


\section{Introduction}

The drilling, extraction, refinery, transportation, storage and consumption of oil and gas are inherently risky ventures. Accidental oil spills are inevitable due to technical, logistical, human, policy, market, financial, political, geologic and environmental factors that influence or compromise the safety of oil rig operations. Management of oil wells and drilling operations turn to be complex due to a number of multi-national companies involved. Ownership, mergers, strategic agreements, contracts, and resulting roles and responsibilities of actors leave much to be desired. The Deepwater Horizon in the Gulf of Mexico was built by Hyundai. The rig was contracted out to British Petroleum (BP) to operate the Macondo oil well. BP was the operator and principal developer of the Macondo Prospect. BP purchased the drilling rights from the US Minerals Management Service (MME) in March 2008. However, the unit was operated by Transocean Management Ltd under contract for BP. Transocean is the world's largest offshore drilling contractor, with a current fleet of some 139 mobile offshore units. Sub-contractors, such as Halliburton Energy Services is the provider of the engineering services, materials, testing, mixing, and pumping for cementing operations. Weatherford has been involved in casting components including the float collar, shoe and centralisers, Dril-Quip, a provider of wellhead equipment, including casting hangers, seal assembly, and lockdown sleeve used on the well and Oceaneering is responsible for remote-operated vehicle (ROV) equipment and personnel (Lee \& Garza-Gomez, 2012).

On April 20, 2010, Deepwater Horizon, a drilling rig owned by Transocean and leased by BP to explore the Macondo oil field, exploded, caught fire, and sank resulting in the death of 11 rig workers and several people sustained varying degrees of physical and psychological injuries (National Commission, 2011). Investigations into the accident revealed that there was recurring theme of missed warning signals, failure to share information, oversight, and a general lack of appreciation of the risks. Ironically, stakeholders involved in the oil drilling blamed and counter-blamed each other for the disaster. Attempts made by reporters to uncover the cause of the rig explosion was met by refusal of company officials to speak with reporters, intimidation of workers who divulge information, suspicion of foul play by sub-contractors and stonewalling of government officials during congressional hearings.

This paper provides a brief history of oil drilling in the US and chronicles cases of oil disasters around the world. It examines technologies that are employed for deep sea oil drilling and investigates and synthesizes the underlying factors that accounted for the Deepwater Horizon oil rig explosion and subsequent oil spillage. The spatio-temporal scale of the oil spill and the economic, social and ecological impacts are presented. In addition, the paper analyzes the complex and diverse issues that emerged before, during and after the oil rig explosion.

\section{Evolution of Oil Drilling in the US}

Beginning in the 1890s, oil companies had drilled wells in the ocean, but from wooden piers connected to the shore. In the 1930s, Texaco and Shell Oil deployed moveable barges to drill in the south Louisiana marshes, protected from extreme conditions in the ocean. In 1937, two independent firms, Pure Oil and Superior Oil, finally plunged away from the shoreline, hiring 
Texas construction company Brown \& Root to build the first freestanding structure in the ocean. It was located in the Gulf of Mexico State Lease No. 1, in 4.27 meter of water, a 2.41 kilometers offshore and 20.92 kilometers from Cameron, Louisiana. In March 1938, this structure brought in the first well from what was named the Creole Field (National Commission, 2011). The Creole platform severed oil extraction from land-and did so profitably, setting in motion the march of innovation into ever-deeper waters and new geological environments offshore. The Gulf of Mexico, where offshore drilling began, remained a vital source of oil and gas for the United States.

On January 28, 1969, a blowout on Union Oil Company Platform A-21 in the Santa Barbara Channel released about 2071.99 square kilometers slick of oil that blackened an estimated 30 miles of California beaches and lethally soaked sea birds in the gooey mess. Although the well's blowout preventer worked, an inadequate well design allowed the hydrocarbons to escape through near-surface ruptures beneath the seafloor. It drew a $\$ 31.5$ million suit against the company by Louisiana oyster fishermen and a $\$ 70$ million suit from shrimp fishermen (National Commission, 2011). During the 1970s and 1980s, the frequency of blowouts did not decline significantly, but there was a sharp drop in the number of catastrophic blowouts, and fewer casualties and fatalities were associated with them (Danenberger, 1993). U.S. oil production peaked in 1970. Along with the OPEC oil embargo of 1973 and consequent skyrocketing price of oil products, this event spurred the quest to develop new offshore reserves.

A major oil disaster occurred on March 1989, the supertanker, Exxon Valdez ran aground on Bligh Reef in Prince William Sound, Alaska (Table 1). The tanker was loaded with about 1.2 million barrels of oil. Close to 250000 barrels was spilled into what is considered to be one of the most pristine and ecologically rich marine environments of the world (Botkin et al., 2006). It caused the death of estimated $13 \%$ of harbour seals, $28 \%$ of sea otters and 100000 645000 seabirds (Botkin et al., 2006). It resulted in the passage of the U.S. Oil Pollution Act of 1990. It cost more than U.S. \$3 billion to clean up but the use of high-pressure hot water and the spraying of rocks also caused further death to organisms found along the shoreline.

Another accident happened in the Galapagos Island in January 2001 when small oil tanker (Jessica) carrying light diesel oil made a navigational error along the coast of Ecuador and spilled diesel into the ocean (Table 1). The United States government responded quickly with Coast Guard ship which pumped oil from the damaged tanker. Some of the oil was washed ashore onto a small island, injuring birds, seals, and other marine life. Many experts and analysts believe that the more recent episode in the Gulf of Mexico in April 2010 is the largest accidental marine oil spill in the history of the petroleum industry. 
Table 1. Chronology of major oil disasters and spills

\begin{tabular}{lll}
\hline Year & Company/Vessel & Location \\
\hline 2010 & Deepwater Horizon & Gulf of Mexico \\
2009 & Montara & Australia \\
2002 & Prestige & Spain \\
1999 & Erika & France \\
1996 & Sea Empress & United Kingdom \\
1991 & ABT Summer & Angola \\
1991 & Haven & Italy \\
1989 & Exxon Valdez & Alaska \\
1989 & Khark 5 & Spain \\
1988 & Odyssey & Canada \\
$1984-85$ & Nowruz & Iran \\
1883 & Castillo de Bellver & South Africa \\
1980 & Funiwa 5 & Nigeria \\
1979 & Atlantic Express & Trinidad \& Tobago \\
1979 & Ixtoc 1 & Mexico \\
1978 & Amoco Cadiz & France \\
1977 & Ekofisk & Norway \\
1974 & Metula & Chile \\
1972 & Sea Star & Gulf of Oman \\
\hline
\end{tabular}

Source: Adapted from ITOPF and Jernelov, 2010

\section{Basic Knowledge of Deep Water Oil and Gas Prospection and Drilling Techniques}

The deepwater environment is cold, dark, distant and under high pressures and the oil and gas reservoirs, when found deep in the Earth, exist at even higher pressures (thousands of pounds per square inch). Superior techniques now allow scientists to virtually see the interior of the oil and gas field or sea-bed formation. Then, super computers process the data to create fully visualized multi-dimensional representations of the sub-surface. Recently, magnetic and seismic surveying are employed. A compressed air gun is used to create shock waves that travel under the surface of the Earth. These reflections are known to travel at varying speeds depending on the rock layers density through which they pass. Sensitive vibration detectors are then used to detect these reflections of the sent shock waves.

Upon completion of surveying, they identify the best location to drill an exploratory well; the area is marked using marker buoys. Exploratory drills are brought forward and if government permission is granted, the drilling process then takes place to determine where hydrocarbons are present, accumulated and to measure the area and thickness of the oil-bearing reservoir (U.S. Department of Energy, 2006). The technology used for the Gulf of Mexico is made up of two parts. First, the oil crew drill several holes which allow the rig to pass through. A rectangular pit is dug around the actual drilling hole to give space for the drilling accessories and the workers. Once the drill reaches the oil deposits, the well needs to be sealed for production and usually a mixture of mud or seawater is used to hold the plug in place until a 
more permanent cap can be applied.

Deep-sea oil drilling involves drilling into the Earth's crust at a 90 degree angle, and rocks are fractured by a highly pressurized mixture of water and sand to keep the crack open (Colleran, 2010). The drilling column is also capable of changing pressure inside the drill to form a seal around the well. Each well, indeed, has its own "personality" that requires maintaining an extremely delicate balance between the counteracting pressures of the sub-surface formation and drilling operation. Drilling mud, which is used to lubricate and cool the drill bit, plays a critical role in controlling the hydrocarbon pressure in the well. The weight of the column of mud in a well exerts pressure that counterbalances the pressure in the hydrocarbon formation. However, if the mud weight is too high, it can fracture the surrounding rock, potentially leading to "lost returns"-leakage of the mud into the formation (National Commission, 2011). It is a delicate balance. The drillers must balance the reservoir pressure (pore pressure) pushing hydrocarbons into the well with counter-pressure from inside the wellbore. An uncontrolled discharge of oil and gas in the well is known as a blowout. Under such conditions, methane hydrates or gas locked in ice ("fire ice") forms at low temperature and high pressure can often be found in sea-floor sediments. Temperature and pressure changes caused by drilling can activate the release of 4.53 cubic metres of gas from 0.028 cubic metres of methane, collapsing surrounding sediments (Boatman and Peterson, 2000).

\section{The Macondo Oil Rig Explosion: Course and Causes}

BP's Macando well was located in 1500 metres of water 75 kilometres southeast of Grand Island, Louisiana (McDonald, 2010). The Macondo oil rig explosion in the Gulf of Mexico on April 20, 2010 appears to have been caused by a bubble of methane gas which escaped from the well, moved up the drill column and ignited. The first explosion occurred at approximately 9:49 p.m. It burst through the floor of the rig and an intense fire engulfed the platform (Tromans, 2010). On the drilling floor, the Macondo disaster claimed the lives of 11 men who worked on the rig, and seriously injured many others. The unit burned for over a day, sank on April 22, and now lies at the bottom of the Gulf of Mexico. The initial oil spill was discovered by BP but it was not reported immediately which suggests an attempt to cover up. The first reports of the oil leak came on April 22, 2010, when a large slick was observed by the US Coast Guard.

The Macondo blowout was the product of several individual missteps and oversights by BP, Halliburton, Transocean and government regulators. The tragic explosion and oil spill revealed a corporate culture at BP that had consistently neglected worker safety and environmental standards by using cost-cutting and poor quality methods (Su et al., 2009). A report released by BP revealed that decisions made by multiple companies and work teams contributed to the accident which arose from a complex and interlinked series of mechanical failures, human judgments, engineering design, operational implementation and team interfaces (BP, 2010a). The National Commission on the BP Deep Horizon oil spill (2011) indicated that BP did not engage in corporate social responsibility (CSR) at the management level and importantly did not act in socially responsible ways. There were several missteps 
and the Commission (2011) of inquiry into the causes of the accident identified the following problems:

(1) There was no standard procedure for running or interpreting the test in either regulations or written industry protocols.

(2) BP and Transocean had no internal procedures for running or interpreting negative-pressure tests and had not formally trained their personnel to do so.

(3) The BP Macondo team did not provide the well site leaders or rig crew with specific procedures for performing negative-pressure tests at Macondo.

(4) BP did not have in place (or did not enforce) any policy that would have required personnel to call back to shore for a second opinion about confusing data.

(5) Finally, due to poor communication, it does not appear that the men performing and interpreting the test had a full appreciation of the fact that the well lack integrity (National Commission on BP Oil Spill, 2011).

Also, investigations revealed that some of the software did not work as expected because the drill control display screens were shut down on numerous occasions before the explosion. A chief engineer of Transocean reported after the accident that the screens froze and locked all the data. This prevented them from reporting the problem properly and promptly. Other software problems include missed and erroneous alarms that caused severe damage to the rig equipment.

After the first explosion, crewmembers on the bridge attempted to engage the rig's emergency disconnect system (EDS). The EDS should have closed the blind shear ram, severed the drill pipe, sealed the well, and disconnected the rig from the Blowout Preventer but none of that happened. The crew should have diverted the flow overboard when mud started spewing from the rig floor. When BP management realized that the early efforts to stop the flow of oil had failed, a primary option was to drill a relief well to intersect the Macondo well at its source and enable a drilling rig to pump in cement to stop the flow of oil.

A device known as a packer is sent down to reinforce the walls, by expanding against the wall to prevent cave-ins and leaks. The most crucial part of the whole system is the blowout preventer. This is a structure with a series of valves used to control the flow of oil from the well, seal off the wellhead and to prevent a "blowout". A blowout preventer (weighing 204 116.6 kilograms) stops oil from gushing out. Unfortunately, the Macondo blowout occurred because bubble of highly inflammable methane gas escaped up the shaft and ignited, causing the explosion (Figure 1). 


\section{$\triangle$ Macrothink}

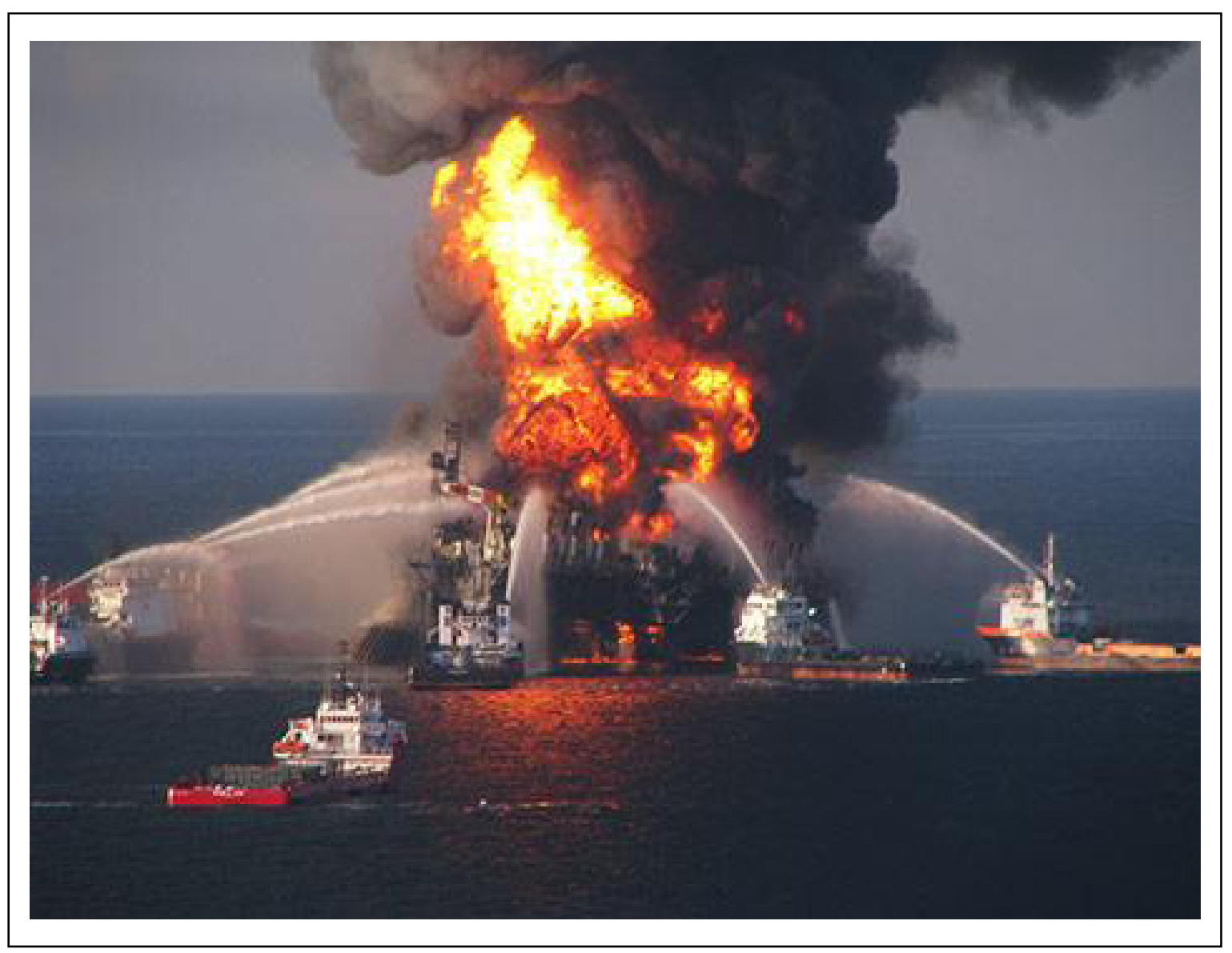

Figure 1. Explosion of Oil Rig (Burning Deep Water Horizon)

Source: US Coast Guard, 2010.

Each of the mistakes made on the rig and onshore by industry and government increased the risk of the well blowout; the cumulative risk that resulted from these decisions and actions was both unreasonably large and avoidable. BP blamed its contractor Transocean for failing to prevent the disaster while Transocean blamed BP for not heeding the safety related warnings Transocean gave. BP in turn blamed Halliburton for poor quality of the cementing, which allowed hydrocarbon to get into the well. Halliburton was criticized for failing to highlight the problems of the cement testing by burying the report which had revealed that the cementing process did not meet industry standards. The Congressional investigation revealed that BP officials and Chief Executive, Tony Hayward had chosen the riskier type of well casing in order to reduce costs and save time, only days before the blowout. Other problems include repeated losses of power and the malfunctioning of a key computer system used to monitor drilling operations. All of the problems had a common link in that they involved bad decisions, missed warnings and worker disagreements.

Government also failed to provide the oversight necessary for ensuring that BP officials and crew abide by standard safety measures. The government did not require industry to do negative pressure test which was a major contributor to the Macondo blowout. It is also 
obvious that regulators failed to ask tougher questions regarding safety because they lacked the skill and technical knowledge for effective supervision.

The oil reservoir contained 110 million barrels of oil (BP, 2010b). MacDonald (2012) indicated that "responders had three options listed in roughly descending order of reliability to estimate the total discharge rate of oil: (1) use technical means - seabed sensors and videos - to quantify the flow from the discharging jets; (2) model from the geological and engineering data already known about the reservoir and well from the exploration drilling that Deepwater Horizon had completed just before the accident; or (3) quantify the amount of oil arriving at the surface of the ocean, and back-calculate a discharge rate from that. Eventually, the authorities would come to rely on methods (1) and (2), analyzing video footage from cameras on remotely operated submersible vehicles with a quantitative visual technique called particle imaging velocimetry". Initially, BP claimed that 1000 barrels of oil per a day was spewing out from the well. However, this flow rate changed to 5000 barrels per a day. After extreme public pressure on BP, the flow-rate was estimated at 55000 barrels per day. Eventually, The Flow Rate Technical Group estimated that the leak initially produced 62000 barrels of oil a day and eased to 53000 barrels a day as the reservoir gradually depleted itself. On August 4, 2010, a Federal government document titled, "Oil Budget" provided the government's first public estimate of the total volume of oil discharged during the spill at roughly 4.9 million barrels (National Commission on BP oil Spill, 2011). The government arrived at this figure using its current flow-rate estimate, which ranges from 62200 barrels per a day on April 22 to 52700 barrels per day on July 14 making it the worst accidental oil discharge in US history (National Commission on Oil Spill 2011).

The true figure was 58000 barrels a day leaking into the Gulf of Mexico (MacDonald, 2010). Some analysts believe that the uncertainty in judgment about flow rate caused more harm. This explains why a containment dome placed on the riser in May failed. It could not handle the rate of flow and within less than an hour became clogged with gas hydrate ice (MacDonald, 2010). In addition, the "top kill" attempt to plug the well with drilling mud did not succeed because of the enormous pressure of the oil and gas discharge.

It was only when the Flow Rate Technical Group began to have credible numbers for discharge and reservoir pressure and trends over time that the responders gained the confidence to unbolt the broken flange and bolt a new, closable cap in place to shut off the discharge. The oil spill lasted for 86 days and spread across 2322.576 to 6317 square kilometre of water (Cleveland, 2010). By the time the Deepwater Horizon well was finally plugged on 15 July, it had spewed some 750 million litres of crude oil into the Gulf (Mascarelli, 2010). The oil spread was not localized as it was moved much faster by strong southern winds and ocean current. BP has recovered about 800000 barrels, or roughly 17\%, during its containment efforts.

\section{Assessment of the Socio-economic Impacts of the Oil Spill}

A number of economic activities were hard hit by the oil spill including stocks, oil industry, real estate, tourism industry and commercial fishing. The oil spill resulted in significant losses to investors in the oil industry around the world. Also, BP cut its dividend payments 
for 2010, and investors turned to alternative companies such as Royal Dutch Shell (BP's competitor) in order to obtain more profit. At the time the leak was sealed, the spill had resulted in a net loss of approximately $\$ 61$ billion to BP, $\$ 17$ billion to partners, $\$ 13$ billion to the drilling sub-industry, and $\$ 19.0$ billion to other integrated oil and gas firms (Lee \& Garza-Gomez, 2012). Competition effects were also found for firms and sectors of the oil and gas industry not related with BP and/or drilling. The market capitalisation of BP went up and down as more news about the oil spill became public. BP's market-adjusted loss in value for the entire episode was $\$ 61$ billion (Lee \& Garza-Gomez, 2012).

The Gulf region accounts for about a fifth of the nation's oyster production and 75 percent of the domestic shrimp output (U.S. Department of Energy, 2006). Louisiana's seafood industry supplies up to 40 percent of US seafood supply and is the second biggest US seafood harvester. Oystermen witnessed multi-generation family businesses slipped away as the demand for seafood from the Gulf fell as a result of consumer wariness, perceptions and fears of tainted seafood and soiled beaches.

By May 2010, commercial and recreational fishing in Mississippi, Alabama and Louisiana were also affected by the oil spill. Louisiana's Governor declared a state of emergency on April 29, 2010. Real estate surrounding areas of the Gulf fell to about 10 percent erasing about $\$ 4.3$ billion in value and job losses could total 1 million over next 5 years. Property owners also lost value on their properties because of the damage from the oil spill.

The means of support for oil-rig workers were temporarily derailed by a blanket drilling moratorium, shutting down all deepwater drilling rigs, including those not implicated in the BP spill. Thousands of people whose livelihood depended on tourism or harvesting marine life remain unemployed. It was reported that Louisiana had a $6.2 \%$ unemployment rate due to the moratorium. Small businesses like souvenir shops, restaurants, bars and even the priest at the local church in Louisiana filed a business loss claim against BP.

\section{Health Vulnerabilities of the Oil Spill}

The unquestionable trauma of losing colleagues, the terror of the explosions, fires, the harrowing rescue has left indelible imprints on the memories of survivors of the oil rig explosion. "Our people are used to tragedies and pulling themselves up from their bootstraps . . . but no one is saved from depression and fear," said Sharon Gauthe, Executive Director of Bayou Interfaith Shared Community Organizing. Although many of the behavioral and psychological effects of the oil spill remain unknown, a Gallup survey of nearly 2600 residents revealed that medical diagnoses of depressive illness in residents of the Gulf region has increased by 25 percent since the rig explosion. Important symptoms include depression, substance abuse, domestic violence, psychological disorders and disruption of family structures (Braud \& Kruse, 2009). Psychological effects and depressive illnesses have worsened as issues of fault and compensation are negotiated or litigated over extended periods (Braud \& Kruse, 2009). Unfortunately, not all medical conditions are covered. Gulf Coast Compensation Fund has maintained that it will not pay damages for mental illness caused by the oil spill (Arata et al., 2000). 
The four classes of hydrocarbons in crude oil are saturates, aromatics, asphaltenes, and resins (Leahy \& Colwell 1990); Polycyclic aromatic hydrocarbons (PAHs) have unique structure and bonding and this increase their solubility and, therefore, their ability to influence various enzyme-mediated reactions in biota. Due to their toxic and mutagenic effects, aromatic compounds are the most environmentally significant of all compounds in crude oils (Mendelssohn, 2012). Fresh oil is more toxic than weathered crude oil because the concentration of volatile organic compounds (VOCs) decreases with weathering. Studies have shown that alkyl nitrates, methane, hexane and butane compounds from the oil can irritate or burn skin and eyes or cause dizziness. These chemicals have been associated with miscarriages and damaged airways. The smell of oil causes severe headaches, nausea, respiratory problems, burning eyes and sore throats (Goldenber, 2010). Several clean-up workers who were deploying booms were hospitalized due to respiratory and dermatological health problems believed to be caused by the fumes and odors of evaporating hydrocarbons.

Some scientists suggested that the use of chemical dispersants (Corexit EC9527A and Corexit EC9500A) which contain 2-Butoxyethanol, propylene glycol and dioctyl sodium sulfosuccinate could have significant side effect (Bolstad, 2010). Other stakeholders objected the use of these dispersants after 2-butoxyethanol was identified as the agent causing health problems of clean up volunteers which are similar to those experienced by workers involved in the 1989 Exxon Valdez oil spill in Alaska. Corexit 9500 is currently banned in British waters due to its potential health risks to cleanup workers (Levy \& Chennat, 2010). Critics pointed out that BP's decision to use Corexit was not motivated by factors laid out by BP but by the close business relationship that BP had with its manufacturer Nalco (Bolstad, 2010).

The negative health and environmental problems of the oil spill increases as the slick is dragged and crept closer to the shoreline. Oil slick along the coastal beaches is an eyesore and this taints the aesthetic and ecological value of beaches.

\section{Environmental Impacts of Oil Spill}

The degree of adverse impact of oil on biophysical environments depends on the chemical content of oil. Different hydrocarbons in crude oil are saturates, aromatics, asphaltenes, and resins. Saturates and aromatics generally dominate. Saturate hydrocarbons, which contain straight-chain, branched, and cyclic structures, constitute the greatest percentage of crude oil. The majority of crude oils encountered in oil spills contain straight-chain hydrocarbon molecules, ranging from single-carbon methane to molecules that contain in excess of 35 carbons, with associated branched and cyclic hydrocarbon structures (Mendelssohn, et al., 2012). Some of the saturate C19-C30 cyclic hydrocarbons are particularly resistant to biodegradation and serve as crude-oil biomarkers. Asphaltenes-large-molecular-weight hydrocarbons containing trace amounts of nickel and vanadium-are even more resistant to microbial degradation and are commonly used as roofing tar and road asphalt (Mendelssohn, et al., 2012).

Identifying and quantifying environmental damages caused by the oil spill, particularly in complex and dynamic ecosystems, present enormous challenges. The National Wildlife Federation stressed that the full impact of the oil spill on the environment may not be known 


\section{Ml Macrothink}

for months or years to come. Jane Lubchenco, head of the National Oceanic and Atmospheric Administration (NOAA) said they are concerned about the long-term impacts, both on the marshes and the wildlife. Most fishery species spawn in near shore or offshore waters of Gulf of Mexico. Species in their early life stages enter estuaries and use the shallow wetlands therein as nursery and rearing areas. Estuaries within the Mississippi River Delta provide habitat for estuary-dependent species. Nektonic species may be directly exposed to oil when they swim through concentrations of dissolved or suspended petroleum constituents. Oil spill damages gill-breathing animals this imperils respiration. The gill uptake results in a body load of toxins that may have lethal or sub-lethal effects (Whitehead, 2011).

Many vulnerable species have been identified, including oysters, shrimps, blue crab, finfish, blue-fin tuna and dolphins. Pelicans were also affected by oil spill as their feathers become coated in oil when they plunge into water (Figure 2). This limits their ability to fly, and lessens their ability to regulate their body heat.

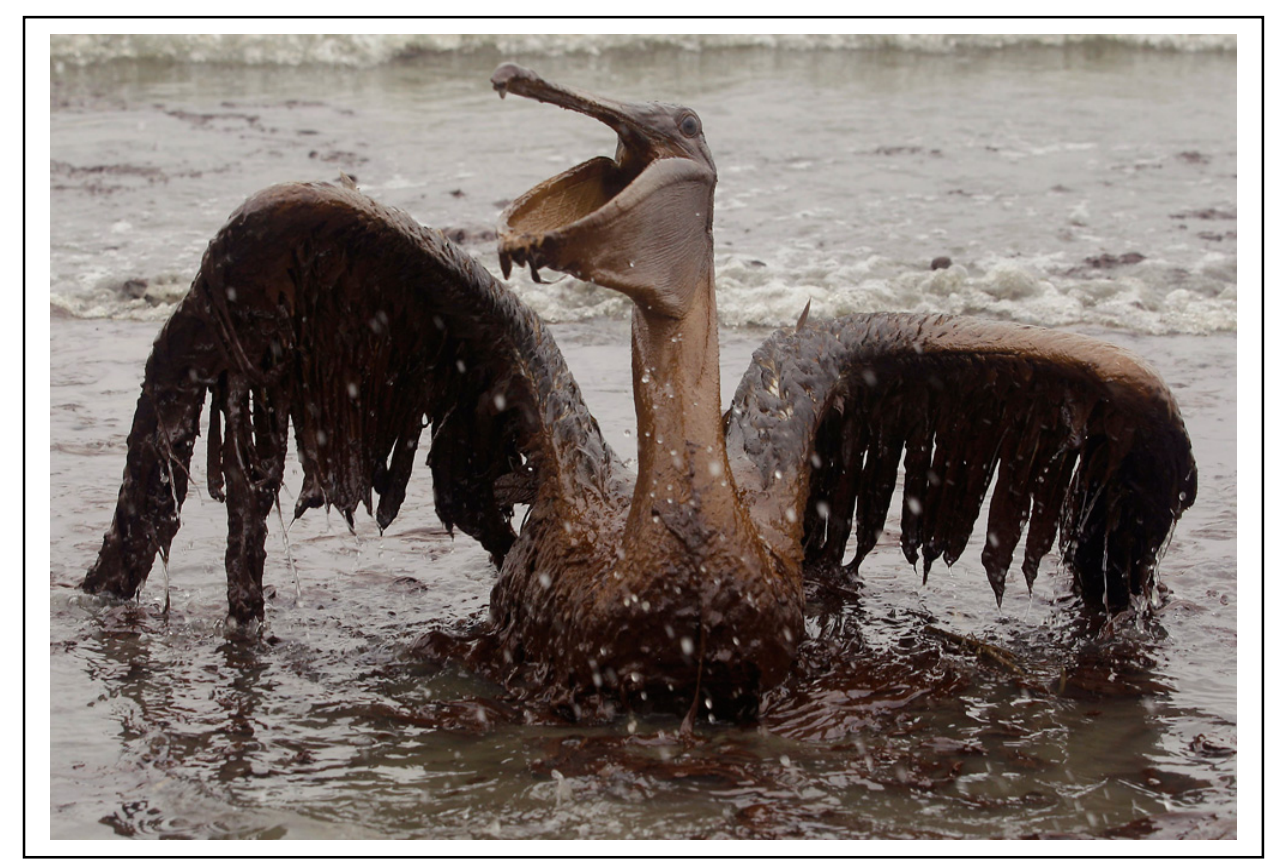

Figure 2. A Brown Pelican coated in oil on the beach at East Grand Terre Island, Louisiana AP Photo by Charlie Riedel 2010.

Sperm whales and Bryde's whales are affected by their ability to reach the surface for oxygen in oil-infested waters. Dolphins are endangered because the other species they consume may be contaminated with oil as a result of biomagnification. Long-lived predatory species such as bluefin tuna, swordfish, marlin and wahoos are affected by the oil spill as the toxins accumulate in species at different levels of the food chain (Gohike et al., 2012). On the sea floor, animals that strain food from the water, including tube worms, clams, mussels and barnacles, could also be exposed to oil micro droplets in the ocean. Louisiana's fragile delta habitats bore the brunt of the damage, with approximately 20 additional miles of Mississippi, 
Alabama, and Florida shorelines moderately to heavily oiled. Clearly, the use of chemical dispersants will cause long-term alternations of marine ecosystems and threaten several species.

A large number of Atlantic tuna at a major spawning site in the Gulf of Mexico probably fell by at least $20 \%$ this year as a result of BP oil spill. The ability of phytoplankton to access sunlight is also affected and this has negative impact on small fish that heavily depends on phytoplankton to survive. Pryosomes die because of hydrocarbons in their tissues and turtles are affected when they ingest pyrosomes. The presence of oil slick prevents seawater from absorbing oxygen from the atmosphere and this threatens countless marine organisms. Digestion of high amounts of underwater oil plumes and methane by microbial organisms in the gulf's depths could lead to oxygen depletion.

\section{Management of the Impact of the Oil Spill}

After several failed attempts to cap the well, BP used a procedure called "top kill" and "junk shot". A top kill —also known as a momentum or dynamic kill—involves pumping heavy drilling mud into the top of the well through the BOP's choke and kill lines, at rates and pressures high enough to force escaping oil back down the well and into the reservoir (National Commission, 2011). The company initiated what is known as the "Static Kill", which essentially is pumping the well with mud until the explosion surrounding it is chocked and stops any further leakage. Engineers pumped mud into the well, waited a few days until it dried, and then started plugging the well. The process went smoothly, and BP finished installing the capping stack without incident by July 12, 2010. Well integrity tests were carried out by monitoring pressure, sonar, acoustic, and visual data continuously. The result of test was positive and the static kill was successful.

Following the incident, President Obama requested a 30-day general safety review of installations. On April 26, 2010, he ordered immediate inspections of all deepwater drilling rigs in the Gulf of Mexico, and careful monitoring of work under existing permits to drill. Secondly, on May 6, 2010, he directed the MMS as a temporary measure to stop issuing new offshore drilling permits pending completion of the review of the adequacy of existing safety systems (National Commission, 2011). The USA senator for Louisiana, Mary Landrieu, testified before this Commission that the moratorium was "unnecessary, ill-conceived and has actually created a second economic disaster for the Gulf Coast by putting thousands of jobs at risk and recommended an immediate termination of a prolonged and arbitrary ban on offshore oil and gas development". Also, based on criticisms from the courts, the Department of the Interior then issued a revised moratorium on July 12, which limited drilling based on the equipment a rig used rather than the depth of the wellhead.

As part of efforts to clean up the oil spill, controlled burn was undertaken and this resulted in release of thick black cloud of smoke into the atmosphere. It has been estimated that only $16 \%$ of the oil spill has evaporated or dissipated naturally and $17 \%$ has been captured by various oil devices. It is still not known the precise amount of oil that still remains in the Gulf, but researchers believe that about $26 \%$ of it is in the Gulf. "Booms" or floating barriers were used on the ocean surface to keep the oil from spreading (Figure 3). Unfortunately, this 


\section{Al Macrothink Institute ${ }^{\text {TM }}$}

technique also failed because the rough sea waves prevented the floating protective booms from being in place properly and caused the oil to sweep over the booms. Booms were not enough and competition for boom occurred at the parish and town levels as well. At a press conference in mid-May 2010, Governor Jindal said that the containment boom provided to Louisiana by the Coast Guard and BP was inadequate.

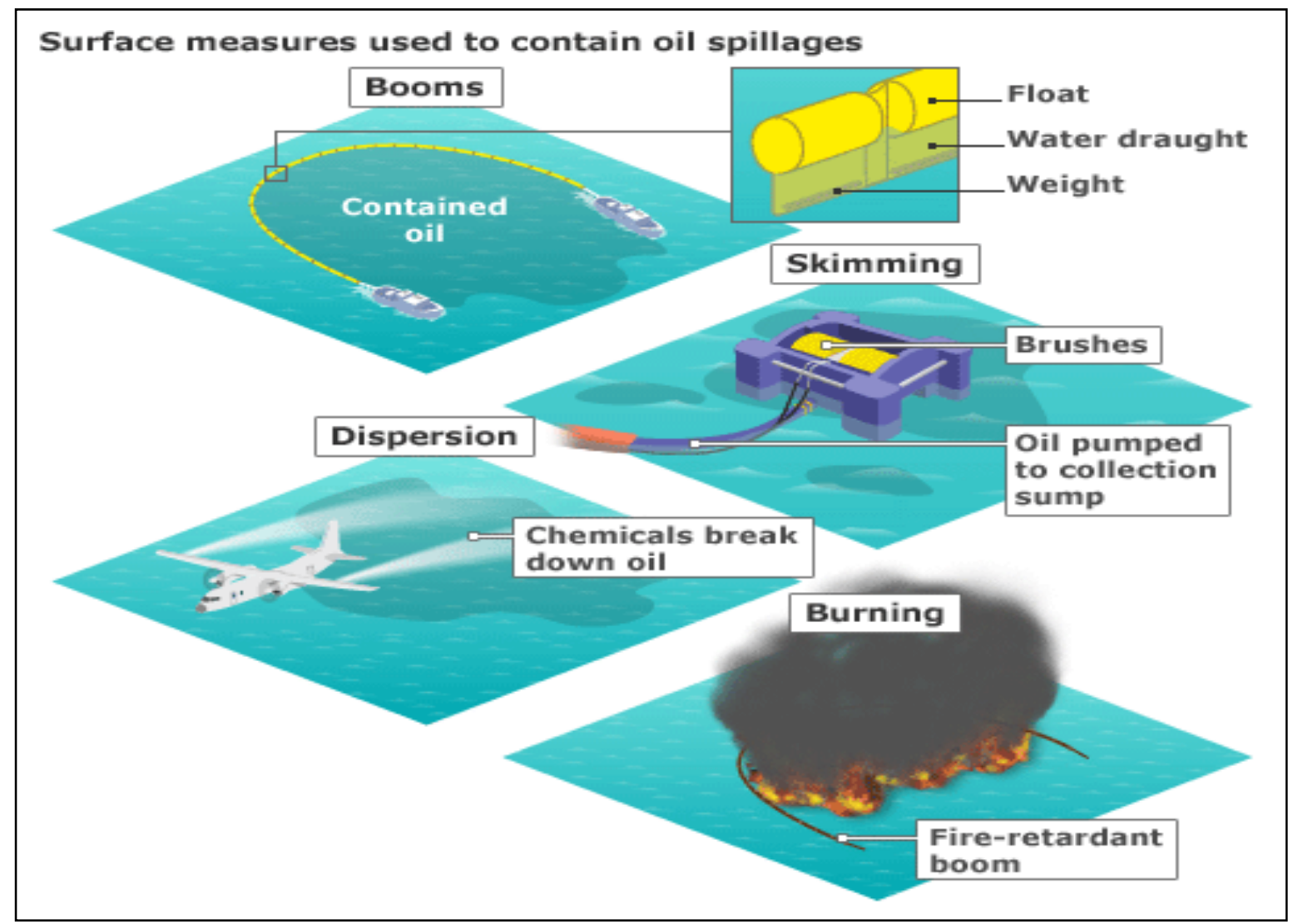

Figure 3. Techniques of cleaning oil

Source: BBC, 2010.

Several small fires were used to reduce the total amount of oil on the surface. Also, oil covered wetlands can be burned in a way that preserves the roots of plants (Kintisch \& Stockstad, 2010). Burning does not remove environmental pollution but rather displaces contaminants from ocean into the atmosphere in the form of nitrogen oxide, carbon monoxide, sulfur dioxide and carbon dioxide which can contribute to acid precipitation, smog problems, greenhouse effect and impact on human health. The U.S. Environmental Protection Agency (EPA) considers ethlybezene, benzene, toluene, and xylene a toxic volatile organic compounds that are released from burning.

BP has also adopted technologies such as the "Sand Shark". The vehicle works as conveyor belt. The sand shark squeaks and shakes as it moves down the beach, scooping up to 2.4384 metres swath of sand polluted with tiny tar balls. It collects sand, removes any hydrocarbons 
and then lays the sand back down.

The Louisiana Department of Wildlife and Fisheries and the Department of Health and Hospitals began closing fisheries and oyster grounds in state waters - three miles or less from shore. Some wildlife that was trapped in the oil spill were rescued and rehabilitated. Experts from the US Fish and Wildlife Service, the National Oceanic and Atmospheric Administration, the National Park Service, as well as state agencies, helped BP to identify the most sensitive wildlife habitats and prioritize appropriate spill countermeasures such as rescue and rehabilitation (oil removal) as well as prevention of the spread of oil to sensitive wildlife areas. Once captured and transported to rehabilitation centers, each animal was individually tagged recorded, cleaned, medically evaluated and assessed by trained wildlife specialists, given appropriate medication, water and food and then monitored, following certified guidelines. BP estimated that 1246 birds, 397 sea turtles, three mammals and more than 14000 sea turtle hatchlings were cared for and released, as of 31 December 2010 (BP, 2010).

\section{Claims and Contingency Plans}

The oil spill spurred many civil, criminal investigations and lawsuits against BP and its stakeholders. Many of the lawsuits are class-actions filed in Texas and Florida. Local businesses filed claims, demanding money for the business lost. BP's own response costs were well in excess of US $\$ 2.5$ billion, including claims paid and federal costs. It is important to note that the US \$20 billion does not represent a cap on BP's liability.

Insurance coverage disputes also seem inevitable. BP itself is understood to have no external insurance in place for the accident. On May 21, 2010, a number of Lloyd's of London syndicates brought proceedings in Houston aimed at disallowing a possible claim for US $\$ 700$ million under a policy held by Transocean. Various shareholder derivative suits and class actions are also under way, on the basis that BP directors breached their fiduciary duties to shareholders by exposing the company to civil and criminal liability.

\section{Conclusion}

The oil spill in the Gulf of Mexico is the largest ecological disaster recorded in recent times. A series of unfortunate events and human error coincided disastrously to cause the rig explosion. Lack of proper inspection and supervision of drilling, cost cutting and quick technical fixes contributed to the disaster. The explosion and subsequent oil spill has left a legacy of toxic pollution that will linger on for many years threatening many already endangered species. For some of the members of the Gulf coast, it will take decades for the effects of contaminated food to be felt in among population as a result of bioaccumulation and biomagnification of toxins in individuals and along the food chain respectively.

Wind systems and ocean currents carried the oil spill far beyond the geographical location of well, increasing the scale and coverage of the spill and complicating the cleanup operations. Although, booms, surface burning, skimming, oil pumps, dispersants, sand sharks techniques were employed, the entire clean-up efforts were carried out in ad-hoc and hotchpotch fashion. Like the Exxon Valdez oil spill, there is still uncertainty about long-term recovery and 
viability of ecosystems and species in the Gulf region.

The painful realization is that this rig explosion and overly extended period of the oil spill could have been prevented if proper procedures were followed before, during and after the spill. It is envisaged that lessons learned from this accident will inspire great technological solutions, pragmatic policies and collective will to deal with future accidents effectively and efficiently.

\section{Recommendations}

Given the bitter lessons from this oil spill, proper government policies and monitoring mechanisms should be established and well qualified oversight committee should be set up to monitor the operations of oil companies in order to prevent such calamities. The oversight committee should be well trained, properly resourced and adequately funded to carry out effective and efficient supervision of oil drilling. Government environmental laws regarding oil drilling should be made more stringent and individual corporate employees who do not comply with these standards should be liable for criminal negligent charges.

The most nerve-racking part of this disaster is how long it took BP to cap the well. The US government was equally helpless in the face of public outcry. This makes one wonder how and why permits for offshore oil exploration could be granted without prudent scrutiny of procedures for preventing and fixing accidents. Future permit conditions should include regular drills, acquisition of well-tested and workable stand-by technology for fixing broken oil wells. This should be backed by refined protocol, organization and management of accidents.

BP should change its philosophy from 'command and control' to 'cooperation and transparency'. BP needs to be open about its operations and affiliated companies should share information, knowledge and expertise before, during and after crises. There is the need for establishing an independent team of oil rig inspectors which should be made of representatives from industry, government, International Standards Organization (ISO), communities and non-government environmental organizations to undertake regular testing, monitoring and assessment of oil rig operations and offer recommendations where necessary. This will provide necessary checks and balances and avoid oversights.

BP needs to put safety concerns first before costs because prevention is cheaper than cure. Careless and ill-conceived short-term cost-cutting measures could result in long-term recurring costs of clean up, claims, property losses etc. It is in the best interest of BP to do the right thing to avert a disaster and uphold its reputation rather than waste billions of dollars on remediation legal battles and reclaiming its image. Given that there were computing and telecommunication system failures prior to the oil rig explosion, BP management should undertake a complete overhaul of their early warning systems in order to install effective monitoring systems with equally efficient and effective back-ups. A well-qualified and dedicated expert should be employed full-time to ensure proper functioning of the safety and communication systems. 


\section{References}

Arata, C., Picou, S. J., Johnson, D., \& McNally, S. T. (2000). Coping with technological disaster: An application of the conservation of resources model to the Exxon Valdez Oil Spill. Journal of traumatic stress, 13(1), 23-39. http://dx.doi.org/10.1023/A:1007764729337

Boatman, M. C., \& Peterson, J. (2000). Oceanic Gas Hydrate Research and Activities Review (OCS Report MMS 2000-017, U.S. Department of Interior, Minerals Management Service, Gulf of Mexico OCS Region.

Bolstad, E. (2010). BP's oil spill caused by fed's "dangerous culture of permissiveness." Common Dreams Organization. Retrieved from http://www.commondreams.org/headline/2010/07/21-1

Botkin, D., Keller, E., \& Heathcote, I. (2006). Environmental science: earth as a living planet Canadian edition. John Wiley \& Sons, Canada Ltd.

Braud, S., \& Kruse, J. (Eds). (2009). Synthesis: Three Decades of Research on Socio-economic Effects Related to Offshore Petroleum Development in Coastal Alaska Minerals Management Service. Alaska region environmental studies. Contract no 1435-01-98-CT-30914.

British Broadcasting Corporation. (2010). Oil spill in Gulf of Mexico in maps and graphics Monday, 12 (Col 4) UK. Retrieved from ttp://news.bbc.co.uk/2/hi/8651333.stm

British Petroleum. (2010a). BP releases report on causes of Gulf of Mexico tragedy. Press release (Press release date: 8 September 2010). Retrieved from http://www.bp.com/genericarticle.do? categoryId=2012968\& contentId=7064893

British Petroleum. (2010b). BP and the Gulf of Mexico Alliance Announce Implementation of BP's $\$ 500$ million. Independent Research Initiative. Press Release, September 29. Retrieved from http://www.bp.com/genericarticle.do? categoryId=2012968\& contentId=7065262

Bureau of Ocean Energy Management. (2009). Regulation and enforcement data provided to the Commission by the Department of the Interior of unannounced MMS inspections of MODUs/drilling rigs, 1990 (1,985 inspections) to 2009 (85 inspections).

Cherry, A. M., \& Sneirson, J. F. (2011). Beyond profit: rethinking corporate social responsibility and greenwashing after the BP oil disaster. Symposium: deep trouble: legal ramifications of the deepwater horizon oil spill. Tulane Law Review Association. 2010, 85(4).

Cleveland, C. (2010). Deepwater Horizon oil spill. In M. C. Hogan, \& P. Saundry (Eds.), The Encyclopedia of Earth. University of California Press.

Coburn, G. (1998). Full Tensor Gradient Method Improves Subsalt Interpretation. Oil \& Gas Journal, 1(10), 11.

Colleran, B. (2010). The Drill's About to Drop. The Environmental Magazine, 21(2), 18-19. 
Danenberger, E. P. (1993). Outer Continental Shelf Drilling Blowouts, 1971-1991. (OTC Paper 7248, Houston, Texas.

Gohike, J. M., Doke, G. D., Tipre, M., Leader, M., \& Fitzgerald, T. (2012). A Review of Seafood Safety after the Deepwater Horizon Blowout. Environmental Health Perspectives, 119(8), 1062-1069.

Goldenber, S. (2010). Gulf oil spill is public health risk, environmental scientists warn. Guardian. Co. UK. 1(28). Retrieved from http://www.guardian.co.uk/environment/2010/may/28/bp-gulf-oil-spill-pollution

Jackson, W. (2010). Oil, risk and technology: the choices we need to make. International Union for Conservation of Nature, 12, 55.

Jernelov, A. (2010). How to defend against future oil spills. Nature, 466(7303), 182-183. http://dx.doi.org/10.1038/466182a

Kelley, T. R. (2010). Environmental health insights into the 2010. Deepwater Horizon (BP) oil blowout. Environmental Health Insights, 4, 61-63. http://dx.doi.org/10.4137/EHI.S5736

Kintisch, E., \& Stockstad, E. (2010). Deepwater Horizon set a new standard for catastrophe? Science, 328(5979), 674-675. http://dx.doi.org/10.1126/science.328.5979.674

Leahy, J. G., \& Colwell, R. R. (1990). Microbial degradation of hydrocarbons in the environment. Microbiological Reviews, 54, 305-315.

Lee, Y., \& Garza-Gomez, X. (2012). Market-based approximation of the cost of non-conformance associated with the 2010 Gulf of Mexico oil spill. Total Quality Management, 23(2), 221-236. http://dx.doi.org/10.1080/14783363.2011.637812

Levy, J., \& Chennat, G. (2010). Promoting ecological sustainability. Journal of Natural Resources Policy Research, 2(3), 297-315. http://dx.doi.org/10.1080/19390459.2010.500462

MacDonald, I. (2010). Best guess versus worse case deepwater disaster: how the oil spill estimates got it wrong. The Royal Statistical Society, 149-154.

Mascarelli, A. (2010). Deepwater Horizon: after the oil. Nature, 467, 22-24. http://dx.doi.org/10.1038/467022a

Mendelssohn, A. I., Andersen, G. L., Baltz, D. M., Caffey, R., Carman K. R., Fleeger J. W., . . L Lawerence, P. R. (2012). oil impacts on coastal wetlands: implications for the Mississippi River Delta ecosystem after the Deepwater Horizon Oil Spill. BioScience, 62, 6.

National Commission on BP Deep Horizon oil spill. (2011). The Gulf oil drilling and the future of offshore drilling. report to the president by the National Commission on the BP Deep Horizon oil spill and the Offshore Drilling Ocean Studies Board and Marine Board (2005) Oil in the sea: inputs, fates, and effects. The National Academies Press, Washington DC

Schaum, J., Cohen, M., Artz, R., Perry, S., Draxler, F. J., Heist, D., . . Philips, L. (2010). 


\section{Macrothink

Screening level assessment of risks due to dioxin emissions from burning oil from the BP Deepwater Horizon Gulf of Mexico spill. Environmental Science \& Technology, 24(44), 9383-9389. http://dx.doi.org/10.1021/es103559w

Shafer, D., \& Laplante, P. A. (2010). The BP Oil Spill: Could software be a culprit? IT professional. September. 6-9. http://dx.doi.org/10.1109/MITP.2010.136

Su, Q., Shi, J., \& Lai, S. (2009). Research on the trade-off relationship within quality costs: A case study. Total Quality Management \& Business Excellence, 20(12), 1395-1405. http://dx.doi.org/10.1080/14783360903248922

Tromans, S. (2010). Deep water horizon and its legal ramifications. International Energy Law Review, 5. Thomson Reuters (Legal), Limited and Contributors.

U. S. Department of Energy. (2006). Environmental benefits of advanced oil and gas exploration and production technology, 17(1), 5.

U.S. Department of the Interior. (1999). Office of Inspector General, Survey Report: Offshore Civil Penalties Program. Minerals Management Service. March 30 http://www.doioig.gov/images/stories/reports/pdf/99-I-374.pdf.

Whitehead, A. (2011). Genomic and physiological footprint of the Deepwater Horizon oil spill on resident marsh fishes. Proceedings of the National Academy of Sciences. http://dx.doi.org/10.1073/pnas.1109545108

Withgott, J., Brennan, S., \& Murck, B. (2010). Environment: the Science behind the stories. Canadian edition. Pearson, Canada.

\section{Copyright Disclaimer}

Copyright reserved by the author(s).

This article is an open-access article distributed under the terms and conditions of the Creative Commons Attribution license (http://creativecommons.org/licenses/by/3.0/). 